\title{
EDITORIAL: IMPACT OF COVID 19 ON TRADE, FDI, REAL EXCHANGE RATE AND ERA OF DIGITALIZATION: BRIEF REVIEW GLOBAL ECONO- MY DURING PANDEMIC
}

\author{
Rossanto Dwi Handoyo* \\ Editor of JDE (Journal of Developing Economies) \\ Department of Economics, Universitas Airlangga, Indonesia \\ E-mail: rossanto_dh@feb.unair.ac.id; rosantodwi@gmail.com
}

To cite this document: Handoyo, R.D., (2020). Impact of Covid 19 on Trade, FDI, Real Exchange Rate and Era of Digitalization: Brief Review Global Economy during Pandemic. JDE (Journal of Developing Economies), Vol. 5 (2), 84-88

\begin{abstract}
The COVID-19 pandemic has not only triggered an unprecedented global health crisis but also a global economic, trade and investment crisis. Global Trade in merchandise fall from $12 \%$ to $32 \%$ in 2020. FDI flows are projected to fall further by $30 \%$ to $40 \%$ in $2020-202$. The decline in trade is a reflection, instead of a cause, of the economic contraction that occurred, caused by rising trade costs - from disruptions in transportation, logistics and supply chains, as well as trade restrictions. At the same time, the COVID-19 pandemic is driving an overall digital transition in society and industry. Since June 2020, there has been increasing trend in social media and other apps, it rose by 38 percent while streaming video increased to 35 percent. A significant increase was in the use of conference tools during the COVID-19 pandemic and it will have an impact on improving technology infrastructure.
\end{abstract}

Keywords: Pandemic COVID-19, Trade in Merchandise, FDI, Exchange Rate and Digitalization

\section{Brief Review Global Economy during Pandemic}

The world economy suffered a downturn during the first half of 2020. COVID-19 has been identified as the cause of the economic recession around the world. The early spread of the COVID-19 virus was found in Wuhan city in Hubei province, China. The virus has spread rapidly across the globe, resulting in tragedy from humanity to tremendous economic damage.

There were more than 39 million cases of COVID-19 globally in mid-October, with more than 1 million deaths. Based on the IMF's (International Monetary Fund) calculations, in 2020, about 3 percent of the global economy will experience a more significant contraction compared to the global financial crisis in 2008-2009 (IMF, 2020a). Various policies have been implemented to prevent the transmission of the COVID-19 virus, namely from social distanc- 
ing activities, lockdown, decreased productivity by companies, and other systems. June 2020 The IMF issued a report stating that the contraction forecast is 4.9 percent, citing worldwide efforts to prevent the spread of COVID-19 (IMF, 2020b).

The COVID-19 pandemic has triggered an unprecedented global health crisis and triggered a global economic, trade, and investment situation. Trade-in merchandise is down $12 \%$ to $32 \%$ in 2020. FDI flows are projected to fall by $30 \%$ to $40 \%$ in $2020-2021$. Trade and investment fluctuations depend on how quickly the pandemic can be controlled. While a crisis can cost unexpectedly, the government can limit spending costs with a variety of policies. The positive impact of the current situation is an opportunity for countries to consider how they can be better prepared in the future. In this sense, global cooperation is essential to solving the global health and economic crisis (G20, 2020).

\section{Impact Covid-19 on Trade, Foreign Direct Investment, and Exchange Rate.}

The Covid-19 pandemic, which has been ongoing since December 2019, has threatened public health globally. The acceleration of widespread transmission to various countries has rapidly expanded into the economic field, creating an international financial crisis. Felsenthal (2020) predicts that global GDP in 2020 will experience a sharp contraction since the Second World War. Many productive activities have been disrupted, both in Asia, Europe, The United States, and other parts of the world. This disrupting activity resulted in a sharp increase in unemployment, especially in North America, which resulted in a decrease in demand for goods and services (ECLAC, 2020). Global trade fell by 5.5\% in October 2020 compared to last year's same period (UNCTAD, 2020). The WTO (2020) expects world trade volume to fall by $9.2 \%$ in 2020 . The decrease in trade in Asia by $4.5 \%$ for exports and $4.4 \%$ for imports in 2020 will be smaller than in other regions. The risk of declining trading volume is still overshadowing, especially if the case of Covid-19 reappears (WTO, 2020).

The decline in trade is a reflection, instead of a cause, of the economic contraction that occurred, caused by rising trade costs - from disruptions in transportation, logistics, and supply chains, as well as trade restrictions. Most countries experienced a decline in international trade in the second quarter of 2020. The sharpest decline occurred in the West and South Asia region, where imports fell by $35 \%$, and exports fell by $41 \%$ (UNCTAD, 2020). The UNCTAD (2020) further explains that the value of trade that provides positive growth comes from the sectors of communication equipment, office machinery, textiles, and clothing, including tools to protect themselves from viruses. Meanwhile, the energy and locomotive sectors are far below the levels of 2019.

The COVID-19 pandemic has severely disrupted the economy, causing labor supply shortages, factory closures, and supply disruptions that have reduced production, leading to massive layoffs, employers, and lost revenue. Increased uncertainty is directing consumers and companies to reduce or delay spending and investment decisions. Similarly, a significant decrease in Foreign Direct Investment (FDI) resulted during the Pandemic COVID-19. Georgieva (2020) states that investors had issued 83 billion US\$ from developing countries since the beginning of the COVID-19 crisis, the most massive capital outflow ever. According to UNCTAD (2020), global FDI flows are expected to shrink between $30 \%$ and $40 \%$ during 2020 . All sectors will be affected, especially in some of the following industries that experienced sharp contractions such as airlines, hotels, restaurants, the recreation industry, and the manufacturing and energy sectors.

During the pandemic, FDI flow decrease compared to the previous year, especially in developing countries in the primary and manufacturing sectors. The OECD (2020) predicts that FDI flows in 2020 will fall by more than $30 \%$ under the most optimistic assumptions in the successful realization of the government's economic and health stimulus policies. Pandemic conditions provide uncertainty in the business world, including in multinational companies. Shocks in demand, supply, including the disruption of the global supply chain, have triggered 
a global recession. Felsenthal (2020) shows that nearly $90 \%$ of multinational companies in the second quarter of 2020 reported experiencing side effects from the pandemic. More specifically, about $80 \%$ of international companies experienced a decrease in net income, resulting in a reduction in investment and employment.

The disruption of global economic activity also impacts international financial vulnerability, especially on the exchange rate volatility in most countries in the world, especially developing countries. The Covid-19 pandemic, directly and indirectly, contributed to a strong global financial market reaction, including high exchange rate volatility. Barro, Weng, \& José (2020) found that increased financial market volatility was influenced by high uncertainty. During the pandemic, exchange rate dynamics occurred similar to the economic dynamics of the global crisis of 2008 and the 2011 eurozone crisis (Liao \& Zhang, 2020).

Park, Rosenkranz, \& Tayag (2020) has recorded a decrease in exchange rate among countries during the first three months of the pandemic; it decreased around $23.6 \%$ in Australia, $22.6 \%$ in Indonesia, and $11.0 \%$ in the Republic of Korea. On the other hand, Rogoff (2020) highlighted that a strengthening exchange rate in developed countries during the COVID-19 pandemic, among others: the euro, has so far appreciated $6 \%$ of the U.S. dollar, the yen-dollar exchange rate barely moved during the pandemic but varied between $¥ 90$ and $¥ 123$ against the dollar during the recession. The diversity of exchange rate responses between developing and developed countries explains global financial vulnerability. While currency weakening occurs in developing countries, there is a strengthening of the U.S. Dollar, increasing the cost of debt payments from developing countries.

\section{Digitalization during Pandemic}

The COVID-19 pandemic has significant changes in all aspects, including the economy, health, and education. At the same time, the COVID-19 pandemic is driving an overall digital transition in society and industry. The efforts to prevent this virus's spread developed new strategies in digitality as an alternative in interacting (Sutera Aru Persada, 2020).

In terms of education, the teacher teaches remotely through a conference or online course. Since the beginning of the school lockdown, universities worldwide are shifting learning to video conference platforms such as Zoom and Google Meet. Moreover, in the health aspects, there was a massive existence of online health services and the development of application systems such as to track patients, remote triage emergency services, etc. (Golinelli et al., 2020). The research conducted by Blockchain (BC) Technology (De', Pandey, \& Pal, 2020), presents an opportunity to create a secure and trusted information control mechanism. There was a shift from offline activities to the digital domain; therefore, BC allows ways to secure and authenticate certificates, health records, medical records, and prescriptions. It indicates that the usage of digital media during this pandemic has increased. Since June 2020, there has been a growing trend in social media and other apps; it rose by 38 percent while streaming video increased to 35 percent. A significant increase was in the use of conference tools during the COVID-19 pandemic, and it will have an impact on improving technology infrastructure. Investment in the expansion of bandwidth, network equipment, and the software will also surge as work from home (Khetarpal, 2020) is established.

\section{References}

Barro, R. J., Weng, J., \& José, U. F. (2020). The Coronavirus and the Great Influenza Pandem ic: Lessons from the "Spanish Flu" for the Coronavirus's Potential Effects on Mortality and Economic Activity. CESifo Working Paper Series. Retrieved from http://www.nber. org/papers/w26866\%0A

De', R., Pandey, N., \& Pal, A. (2020). Impact of digital surge during Covid-19 pandemic: A view 
point on research and practice. International Journal of Information Management, 55. https://doi.org/10.1016/j.ijinfomgt.2020.102171

ECLAC. (2020). The effects of the coronavirus disease (COVID-19) pandemic on internation al trade and logistics. Retrieved from https://www.cepal.org/en/publications/45878effects-coronavirus-disease-covid-19-pandemic-international-trade-and-logistics

Felsenthal, M. (2020). COVID-19 to Plunge Global Economy into Worst Recession since World War II. The World Bank. Retrieved from https://www.worldbank.org/en/news/pressrelease/2020/06/08/covid-19-to-plunge-global-economy-into-worst-recession-sinceworld-war-ii

G20. (2020). COVID-19 Crisis : Implications for Trade and Investment. Retrieved from https:// g20.org/en/media/Documents/G20_TIWG_Implications of COVID-19 for Trade and In vestment_June 2020.pdf

Georgieva, K. (2020). The Great Lockdown: Worst Economic Downturn Since the Great De pression. International Monetary Fund.

Golinelli, D., Boetto, E., Carullo, G., Nuzzolese, A. G., Landini, M. P., \& Fantini, M. P. (2020). How the COVID-19 pandemic favored the adoption of digital technologies in health care: a systematic review of early scientific literature (Preprint). Journal of Medical Internet Research. https://doi.org/10.2196/22280

IMF. (2020a). World Economic Outlook, April 2020: The Great Lockdown. World Economic Out look. Retrieved from https://www.imf.org/en/Publications/WEO/ls sues/2020/04/14/weo-april-2020

IMF. (2020b). World Economic Outlook Update June 2020 : A crisis like no other, an uncertain recovery. International Monetary Fund. Retrieved from https://www. imf.org/en/Publications/WEO/Issues/2020/06/24/WEOUpdateJune2020/

Khetarpal, S. (2020). Post-COVID, 75\% of 4.5 lakh TCS employees to permanently work from home by '25; from $20 \%$. Business Today.

Liao, G., \& Zhang, T. (2020). Currency hedging, exchange rate movement, and dollar swap line usage during the Covid-19 pandemic. Retrieved from https:// voxeu.org/article/currency-hedging-exchange-rate-movement-and-dollar- swap-lineusage-during-covid-19

OECD. (2020). The impact of the coronavirus (COVID-19) crisis on development finance. Tackling Coronavirus (COVID-19) Contributing to a Global Effort, 100(6), 468-470.

Park, C.-Y., Rosenkranz, P., \& Tayag, M. C. (2020). COVID-19 Exposes Asian Banks' Vulnerability to US Dollar Funding. Retrieved from https://www.adb.org/sites/ default/files/publication/616091/covid-19-asian-banks- vulnerability-us-dollar-fund ing.pdf 
Rogoff, K. (2020). Exchange rates have been stable in the Covid crisis - are we heading for a storm? Retrieved from https://www.theguardian.com/business/2020/nov/16/ exchange-rates-covid-crisis- pandemic-us-election

Sutera Aru Persada, F. W. (2020). Dampak Pandemi Covid-19 Modernisasi Dan Digitalisasi Komisi Pemilihan Umum Republik Indonesia (Kpu-Ri). Jurnal IImiah Galuh Jus tisi, 8(2), 18. Retrieved from https://jurnal.unigal.ac.id/index.php/galuhjustisi/ article/view/3513/3285\%0A

UNCTAD. (2020). Global Trade Update. Retrieved from https://unctad.org/ system/files/official-document/ditcinf2020d4_en.pdf WTO. (2020). TRADE STATISTICS AND OUTLOOK: Trade shows signs of rebound from COVID-19, recovery still uncertain. Retrieved from https://www. wto.org/english/news_e/pres20_e/pr862_e.pdf

WTO. (2020). Trade shows signs of rebound from COVID-19, recovery still uncertain. Retrieved from World Trade Organization: https://www.wto.org/english/news_e/pres20_e/ pr862_e.htm 